\title{
PENGENDALIAN HAMA KUTU PUTIH (Bemisa tabaci) PADA BUAH SIRSAK DENGAN MENGGUNAKAN PESTISIDA NABATI EKTRAK \\ SERAI (Cymbopogon nardus L.)
}

\author{
Fahruddin Arfianto \\ Fakultas Pertanian dan Kehutanan Program Studi Argoteknologi \\ Universitas Muhammadiyah Palangkaraya
}

\begin{abstract}
Abstrak
Pestisida merupakan senyawa kimia yang disusun untuk mengendalikan hama dan penyakit yang menyerang tanaman. Di Indonesia pestisida sering digunakan untuk mengendalikan hama dan penyakit yang menyerang tanaman tetapi pada saat ini pestisida banyak ditemukan residu khususnya di tanaman dan tanah sehingga menyebabkan pencemaran lingkungan terutama pestisida kimia.

Pestisida nabati merupakan pestisida yang digunakan untuk pengendalian hamadan penyakit bagi tanaman yang terbuat dari bahan alami seperti minyakatsiri yang dihasilkan oleh tanaman. Pestisida nabati memiliki beberapa keunggulan seperti mudah terurai oleh sinar matahari, tidak menyebabkan gangguan lingkungan.

Tujuan dari penelitian ini adalah 1). Untuk mengetahui cara pembuatan pestisida nabati2). Untuk mengetahui berapa dosis pestisida nabati yang digunakan . Metode yang digunakan adalah aplikasi langsung ketanaman yang terserang hama. pada dua perlakuan dengan dosis berbeda membuktikan bahwa dengan dosis pencampuran $50 \mathrm{ml}$ ekstrak serai dengan $500 \mathrm{ml}$ air lebih efektif mengendalikan hama yang menyerang buah sirsak. Kesimpulan penelitian ini adalah Penggunaan Ekstrak serai $50 \mathrm{ml}$ dengan campuran air sebanyak $500 \mathrm{ml}$ lebih efektif mengendalikan hama kutu kebul yang menyerang buah sirsak.
\end{abstract}

Kata Kunci : Pestisida Nabati, Serai(Cymbopogon nardus L.)

\begin{abstract}
Pesticides are chemical compounds that are structured to control pests and diseases that attack plants. In Indonesia, pesticides are often used to control pests and diseases that attack plants, but at this time, from pesticides are found many residues, especially in plants and soil causing environmental pollution, especially chemical pesticides.

Nabati pesticides are pesticides used for controlling pest and disease for plants made from natural ingredients such as essential oils produced by plants. Nabati pesticides have several advantages such as easily decomposes by sunlight andit does not cause environmental disturbance.

The purpose of this research is 1)To know how to make nabati pesticides 2) To find out how many doses of nabati pesticides are used. The method used in this research is direct application of crops affected by pests. In two treatments with different doses proved that with a mixing dose of $50 \mathrm{ml}$ of serai extract with $500 \mathrm{ml}$ water was more effective in controlling pests that attacked soursop.
\end{abstract}

Keywords: Nabati Pesticide, Serai (Cymbopogon nardus L.) 


\section{PENDAHULUAN}

\section{Latar Belakang}

Pestisida merupakan senyawa kimia yang disusun untuk mengendalikan hama dan penyakit yang menyerang tanaman. Di Indonesia pestisida sering digunakan untuk mengendalikan hama dan penyakit yang menyerang tanaman tetapi pada saat ini pestisida banyak ditemukan residu khususnya di tanaman dan tanah sehingga menyebabkan pencemaran lingkungan terutama pestisida kimia. Pada dasarnya pestisida dibagi menjadi 2 menurut jenisnya yaitu pestisida kimia dan pestisida alami atau nabati. Pestisida kimia merupakan pestisida yang dibuat dari bahan kimia oleh manusia yang berguna dalam pengendalian hama dan penyakit tanaman. Pestisida kimia ini sering memiliki residu kimia yang tinggi baik didalam tanaman ataupun didalam tanah sehingga mengganggu lingkungan. Banyaknya terjadi gangguan lingkungan akibat pestisida kimia sehingga memunculkan suatu ide yaitu Pengendalian Hama Terpadu (PHT) yang salah satu tujuannya adalah mengendalikan hama dengan menggunakan musuh alami dan penggunaan pestisida nabati.

Pestisida nabati merupakan pestisida yang digunakan untuk pengendalian hamadan penyakit bagi tanaman yang terbuat dari bahan alami seperti minyakatsiri yang dihasilkan oleh tanaman. Pestisida nabati memiliki beberapa keunggulan seperti mudah terurai oleh sinar matahari, tidak menyebabkan gangguan lingkungan sedangkan untuk kerugian bagi penggunaan pestisida nabati ini yaitu cara aplikasiannya harus berulang kali karena mudah terurai oleh sinar matahari, harganya tidak terjangkau oleh petani karena pembuatan pestisida ini menggunakan bahan dari alam yang memiliki stok yang tidak mencukupi bagi pembuatan pestisida nabati secara masal. Pestisida memiliki beberapa jenis menurut hama yang akan dikendalikan yaitu insektisida, nematisida, bakterisida dan lain-lain.

Penggunaan pestisida nabati ini diharapkan dapat menekan populasi hama yang menyerang tanaman tetapi penggunaan pestisida ini jarang sekali mematikan hama tetapi hanya menyebabkan toxin pada hama tersebut sepeti racun perut, penguranag nafsu makan hama dan lain-lain. Penyebab tersebut yang mengurangi minat petani untuk menggunakan pestisida nabati karena petani menginginkan hama yang menyerang tanaman dapat langsung mati 
dan populasinya menurun secara drastis tetapi petani tidak memikirkan residu yang akan terjadi pada lingkungan. Penggunaan pestisida kimia juga harus mematuhi peraturan penggunaan seperti menggunakan pakaian yang lengkap ketika dilakukan penyemprotan, menggunakan dosis yang tepat dan lain-lain,

\section{Tujuan}

Untuk mengetahui pengendalian hama kutu dengan menggunakan ekstrak sera

\section{TINJAUAN PUSTAKA}

\section{Pestisida nabati dari Serai}

Tanaman serai atau sereh adalah tanaman anggota suku rumput - rumputan yang dimanfaatkan sebagai bumbu dapur untuk mengharumkan makanan.Serai memiliki nama latin Cymbopogon Nardus $L$, tanaman serai berasal dari selatan india atau srilanka,penyebaran tanamn ini ke negara - negara yang memiliki iklim tropis seperti Asia, Amerika, Afrika dan lain sebagainya.

Dilihat dari segi pertanian, untuk tanaman khususya Pestisida Nabati Alami, Tanaman serai mengandung senyawa Sitronela yang tidak disukai nyamuk dan berbagai serangga.Dengan demikian serai dapat digunakan sebagai Pestisida Alami.Dengan kandungan Minyak Atsiri yang tinggi pada tanaman serai juga dimanfaatkan untuk pertanian organik yang dapat dijadikan sebagai alternatif pestisida anorganik yang berfungsi sebagai bakterisida, insektisida serta nematisida.

Pestisida nabati alami dari tanaman serai ini dapat diterapkan pada tanaman padi, palawija, dan tanaman sayur - sayuran, dikarenkan Pestisida Nabati Alami dari tanaman serai ini tidak mengandung bahan kimia sehingga aman bagi sayuran kalau mau dikonsumsi.Cara menerapkan Pestisida Nabati Alami daritanaman seraiadalah dengan cara disemprotkan ke tanaman yang terkena hama dan penyakit, jika serangan dan penyakit pada tanaman tinggi, maka lakukanlah penyemprotan dengan bertahap sampai hama dan penyakit hilang. (Pembangunan Pertanian Indonesia, 2016)

\section{Klasifikasi Tanaman Sirsak}

Kingdom : Plantae ( Tumbuhan ); Divisi : Magnoliophyta ( Tumbuhan berbunga ) ; Kelas : Magnoliopsida ( berkeping dua / di kotil ) ; Ordo : Magnoliales ; Famili : Annonaceae ; Genus : Anonna ; Spesies : Annona muricata L

\section{Morfologi Tanaman Sirsak}

\section{a. Daun}

Tanaman sirsak memiliki daun berwarna hijau mudah dan tua dengan panjang 6-18 $\mathrm{cm}$, lebar 3-7 cm, berbentuk bulat telur, ujung lancip dan ada juga yang tumpul, 
daun bagian atas mengkilap hujai dan gundul kusam di bagian bawah daun. Daun tanaman sirsak ini memiliki bau yang sangat menyengat dengan tangkai 3-10 $\mathrm{mm}$.

\section{b. Bunga}

Tanaman sirsak memiliki bungkai tunggal dan memiliki berbagai macam putik sehingga di disebut berpistil majemuk. Mahkota bunga berjumlah 6 sepalum terdiri 2 lingkaran, berbentuk segitiga, tebal dan kaku, berwarna kuning keputihan dan setelah tua akan mekar dan menjadi buah .

\section{c. Buah}

Tanaman sirsak memiliki buah berwarna hijau kekuningan jika mulai matang dan hijau muda ketika masih mudah atau mentil.Bentuk buah sirsak oval dan juga yang loncong, dengan strukut kulit berduri kehitaman dan tidak terlalu tajam.Bagian dalam buah ini lembek, berwarna putih dan memiliki biji berwarna kehitaman.

\section{d. Biji}

Tanaman sirsak memiliki biji kehitaman atau coklat berbentuk bulat dan lonjong dengan panang 16,8 mmdan lebar 9,6 $\mathrm{mm}$. Memiliki jumlah yang sangat bervariasi mecapi 20-70 butir biji secara normalnya. Jika biji berwarna putih kecoklatan berarti biji tersebut tidaklah normal.

\section{Klasifikasi Tanaman Serei}

Kingdom : Plantae ; Subkingdom : Trachebionta ; Divisi : Spermatophyta ; Sub Divisi : Angiospermae ; Kelas : Monocotyledonae ; Sub Kelas : Commelinidae ; Ordo : Poales ; Famili : ;Graminae/Poaceae ; Genus : Cymbopogon Species : Cymbopogon nardus L. Rendle

Serai bukanlah sesuatu yang asing bagai kebanyakan ibu-ibu rumah tangga , bagian dari batang serai atau sereh seringkali dijadikan sebagai bumbu masakan. Tanaman yang masih sejenis rumput-rumputan yang dimanfaatkan sebagai sebagai aroma penyedap beberapa jenis masakan tradisional. Pemanfaatan tumbuhan serai ini juga sebagai pengobatan tradisional untuk mengatasi beberapa macam penyakit seperti, batuk, pengencer dahak, keseleo, meredakan nyeri , pengusir nyamuk hingga untuk obat sakit gigi.

Serai mengandung enzim yang bernama sitronella tidak disukai nyamuk dan beberapa serangga lainnya. Oleh karena alasan tersebut, serai dapat digunakan sebagai pestisida atau insektisida organik untuk mengedalikan hama tanaman. Manfaat lainnya dari tanaman sereh bagi pertanianorganik dapat dijadikan sebagai alternative pestisida anorganik (kimia) juga berfungsi 
sebagai bakterisida, insektisida serta nematisida.

Fungsi atau manfaat yang diperoleh dari penggunaan pestisida organik serai (buatan sendiri) berkat adanya kandungan senyawa aktif dari keseluruhan bagian tanaman sereh dalam bentuk minyak atsiri. Adapun zat-zat atau senyawa aktif terdiri dari: dipentena, farnesol, geraniol, mirsena, metil heptenol, nerol dan sitral, sitronella.

Kandungan senyawa aktif tanaman serai dapat mengendalikan hama tanaman termasuk: kutu tanaman, beberapa serangga, (Tribolium sp) ; Sitophilus sp.; Callosobruchus sp. ; Nematoda (Meloidogyne sp.) ; dan Jamur Pseudomonas sp

\section{Kutu Kebul}

Kutu putih atau dikenal Kutu kebul adalah hama yang sering menyerang berbagai macam jenis tanaman, terutamanya tanaman buah, hias, sayuran ataupun tanaman lain. Hama ini akan menyerang pada batang tangkai daun, batang tanaman, buah dan daun.

\section{Klasifikasi Kutu Putih (Kutu Kebul)}

Kingdom : Metazoa ; Phylum : Arthropoda

; Subpylum : Uniramia ; Kelas : Insecta

Ordo : Hemiptera ; Subordo :

Sternorrhyncha ; Superfamily :
Aleyrodoidea ; Famili : Aleyrodidae ; Spesies: Bemisa tabaci

\section{Morfologi Kutu Putih (Kutu Kebul)}

Telur berbentuk elips dengan panjang berkisar 0,2-0,3 $\mathrm{mm}$, telur biasanya diletakan secara berkelompok dibagian permukaan daun dan permukaan buah. Masa inkubasi telur selama 4-6 hari pada suhu $26-32^{\circ} \mathrm{C}$, sedangkan pada suhu 18 $22^{0} \mathrm{C}$ masa inkubasi telur selama 10-16 hari. Jumlah telur yang diletakan di permukaan daun dan buah yang terserang virus berjumlah 77 butir dan pada daun dan buah sehat berjumlah 14 butir (Suharto, 2007).

Bermisia tabaci memiliki tiga instar nimfa, yang akan berlangsung selama 12-15 hari. Panjang tubuh nimfa berkisar 0,2-0,4 mm, berbentuk bulat panjang dengan torak melebar dan cembung serta ruang abdomen terlihat dengan jelas (Anonim, 2011).

Ketika sudah menjadi serangga memiliki panjang 1-1,5 mm, bersayap tipis, dan tubuh serangga memiliki warna putih hingga kekuningan. Serangga yang baru menjadi dewasa akan mengembangkan sayapnya selama 8-15 menit dan kemudian tubuh akan tertutupi tepung lilin (Suharto, 2007). 
Lama hidup Bemasia tabaci tergantung dengan keadaan lingkungan dan faktor lain. Lama hidup imago rata-rata di Indonesia berskiar 6 hari. Namun, secara umumnya serangga jantan umurnya lebih pendek dibandingkan betina berisar 9-17 hari dan betina mencapai 37-74 hari (Suharto, 2007).

\section{METODOLOGI}

\section{Waktu dan Tempat}

Pembuatan pestisida nabati dilaksanakan pada tanggal 23 oktober 2016 di Laboratorium MIPA Universitas Muhammadiyah Palangkaraya J1 RTA Milono Km 1,5 Palangkaraya

\section{Alat dan Bahan}

Alat yang digunakan adalah Pisau, telanan, baskom dan timbangan.BahanAir 2 liter dan 50 gram batang serai

\section{Metode}

Metode yang digunakan adalah
aplikasi langsung ketanaman yang terserang hama dan cara pembuatan ekstrak serai Pertama dimulai dengan memilih batang serai yang masih segar setelah itu memotong batang serai tersebut kecil kecil setelah itu serai ditumbuk atau bisa diblender. sampaibatang serai halus, di lanjutkan dengan merendam dalam air bersih. Lakukan perendaman selama 24 jam, setelah itu saring ekstrak serai sebelum dipergunakan, Aplikasi untuk buah sirsak yang terkena hama dilakukan dengan dua perlakuan dosis yang berbeda.Perlakuan pertama pencampuran $25 \mathrm{ml}$ ekstrak serai dengan $500 \mathrm{ml}$ air dan perlakuan kedua $50 \mathrm{ml}$ ekstrak serai dengan $500 \mathrm{ml}$ air diaplikasikan dengan cara penyemprotan.dengan waktu selama 1 minggu

\section{PEMBAHASAN}

Hasil Penelitian pembuatan pestisida nabati eksrak serai langsungdisemprotkan ke tanaman yang buahnyaterkena kutu kebul selama 1 minggu hasil dapat dilihat pada tabel berikut : 


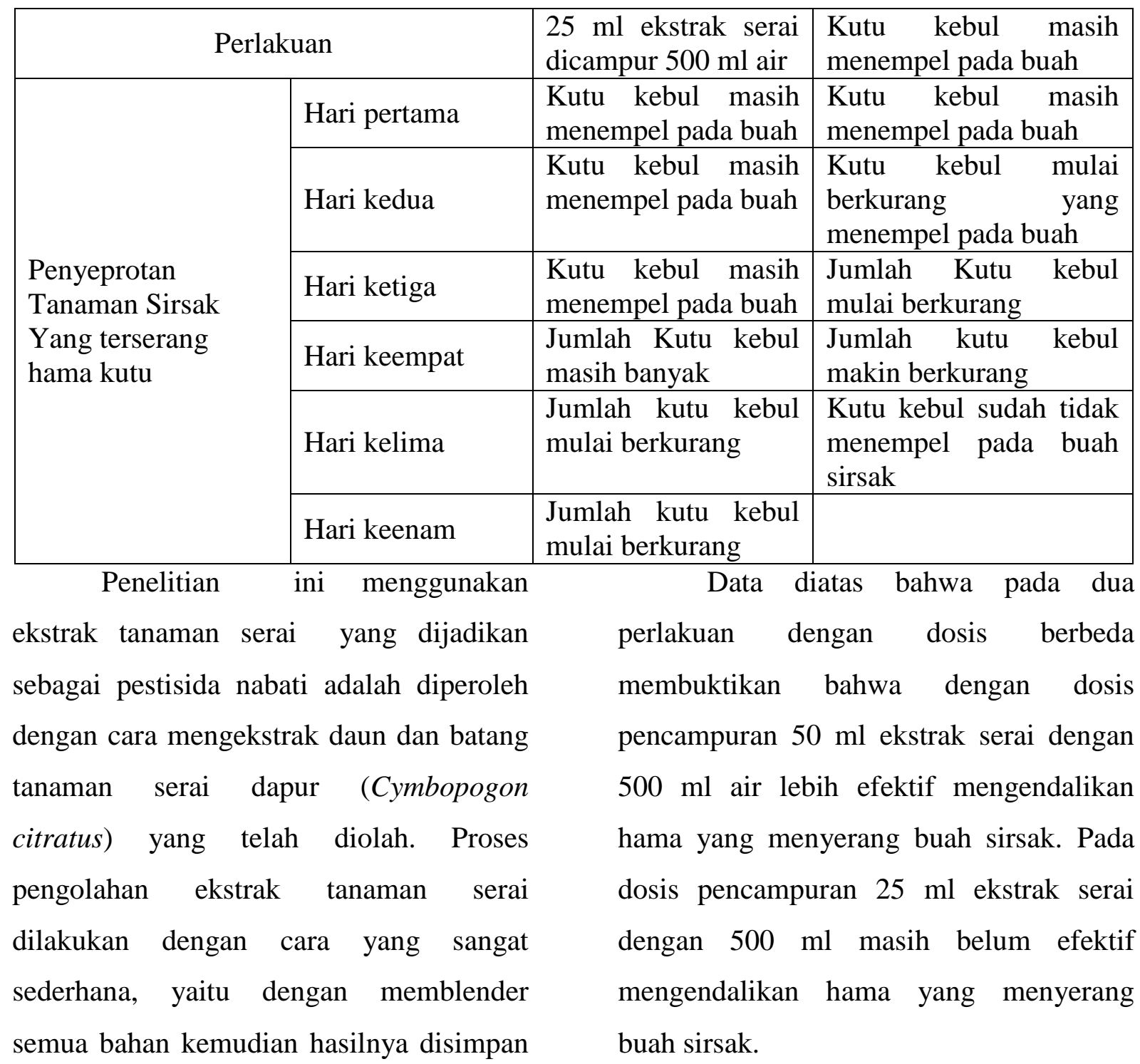

selama satu hari satu malam. Bahan dan cara yang digunakan dalam pembuatan ekstrak tanaman serai sangat sederhana, hanya diperlukan batang dan daun dari tanaman serai, dan yang sudah ditimbang sebagai bahan untuk menghasilkan ekstrak.. disaring setelah proses penyimpanan untuk selanjutnya dapat diaplikasikan setiap hari selama satu minggu pada kisaran jam $15.00 \quad-17.00$ WIB.

Data pengamatan yang telah diperoleh bahwa kutu kebul yang menyerang buah sirsak akan hilang setelah enam hari penyemprotan dengan dosis 50 $\mathrm{ml}$ ekstrak serai dicampur dengan air sebanyak $500 \mathrm{ml}$. Perbedaan terlihat jika dosis ekstrak serai $25 \mathrm{ml}$ pada hari keenam masih terlihat kutu kebul pada buah sirsak . Menurut Herminanto, dkk (2010) semakin tinggi dosis pemakaian ekstrak serai yang dipakai akan meningkatkan daya racun 
yang ditimbulkannya sehingga semakin banyak kematian hama yang terjadi.

Penggunaan pestisida nabati ekstrak serai akan menguntungkan petani sebab ditinjau dari bahan pembuatan mudah didapat dan proses pembuatan sangat mudah tidak memerlukan bahan kimia. Pengendalian hama kutu kebul pada buah sirsak sangat dianjurkan memakai ekstrak serai sebab buah tidak akan terkontaminasi dengan bahan kimia yang akan merusak kualitas buah sirsak.

\section{KESIMPULAN}

Penggunaan Ekstrak serai $50 \mathrm{ml}$ dengan campuran air sebanyak $500 \mathrm{ml}$ lebih efektif mengendalikan hama kutu kebul yang menyerang buah sirsak.

\section{DAFTAR PUSTAKA}

Anonim. 2011. Kutu Kebul (Bemisia tabaci).

http://ditlin.hortikultura.go.id/opt/ tomat/kt_kebul.htm. Diakses 20 Agustus 2011.

Adnyana, dkk.2012. Efikasi Pestisida Nabati Minyak Atsiri Tanaman Tropis terhadap Mortalitas Ulat Bulu Gempinis. Jurnal Agroekologi Tropika 1(1): 1-11.

Fredi Kurniawan, 2018, Klasifikasi dan Morfologi Kutu Kebul, http://fredikurniawan.com/klasifik asi-dan-morfologi-kutu-putih- bemasia-tabaci/ diaksen tanggal 3 Juli 2018.

Kardinan, A. 2002. Pestisida Nabati: Ramuan dan aplikasi. Cetakan ke4. Penebar Swadaya, Jakarta.

Oka, I.N. 1995. Pengendalian Hayati Terpadu dan Implementasinya di Indonesia. Gadjah Mada University Press, Yogyakarta.

Pembanguan Pertanian Indonesia, 2016, Tanaman Serai Sebagai Pestisida Nabati, https://mahasiswapertanian.blogspot.com/2016/10/c ara-membuat-pestisida-nabatialami.html.Diakses tanggal 13 Agustus 2018.

Suharto. 2007. Pengenalan dan Pengendalian Hama Tanaman Pangan. Penerbit ANDI. Yogyakarta.120 halaman.

Setiawati, W, dkk. 2008. Tumbuhan Bahan Pestisida Nabati dan Cara Pembuatannya Untuk Pengendalian Organisme Pengganggu Tumbuhan (Opt). Balai Penelitian Tanaman Sayuran. Bandung.

Tohir, A.M. 2010. Teknik Ekstraksi Dan Aplikasi Beberapa Pestisida Nabati Untuk Menurunkan Palatabilitas Ulat Grayak (Spodoptera Litura Fabr.) Di Laboratorium. Buletin Teknik Pertanian 15(1): 37-40.

Tombe, Mesak. 2008. Pemanfaatan Pestisida Nabati Dan Agensia Hayati Untuk Pengendalian Penyakit Busuk Jamur Akar Putih Pada Jambu Mete. Bulettin Littro 14(1): 68-77. 


\section{Gambar 1. Kutu Kebul}

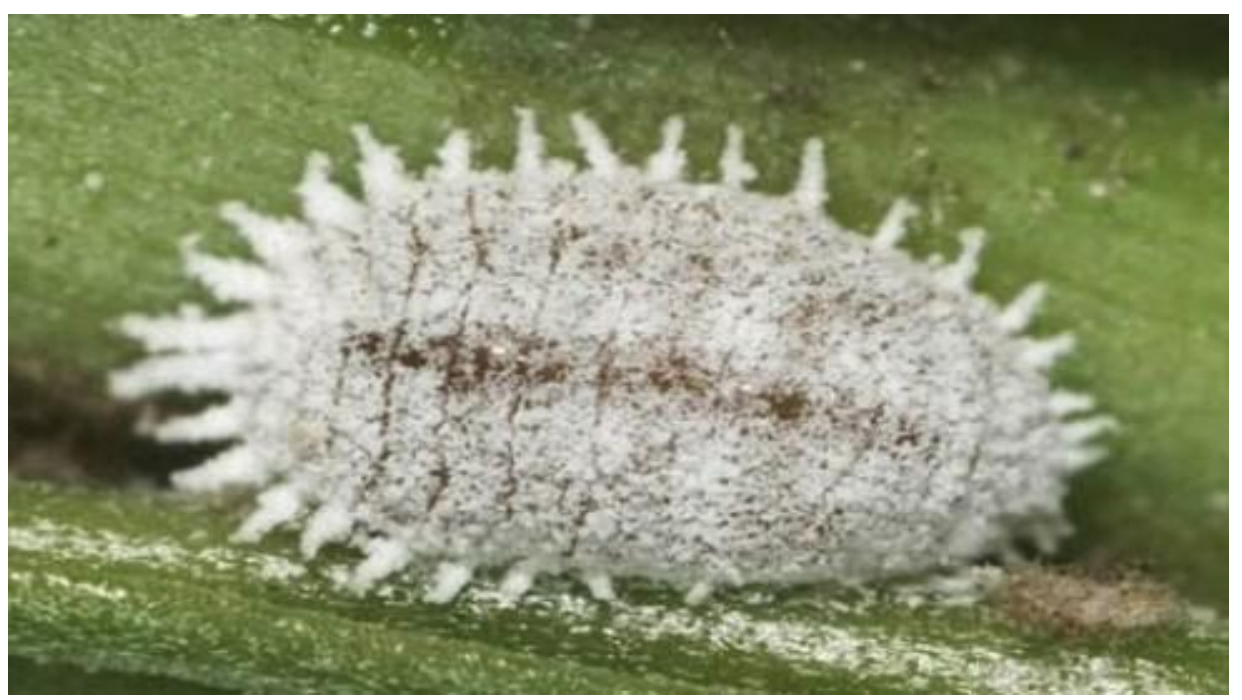

\section{Gambar 2. Tanaman Serai}

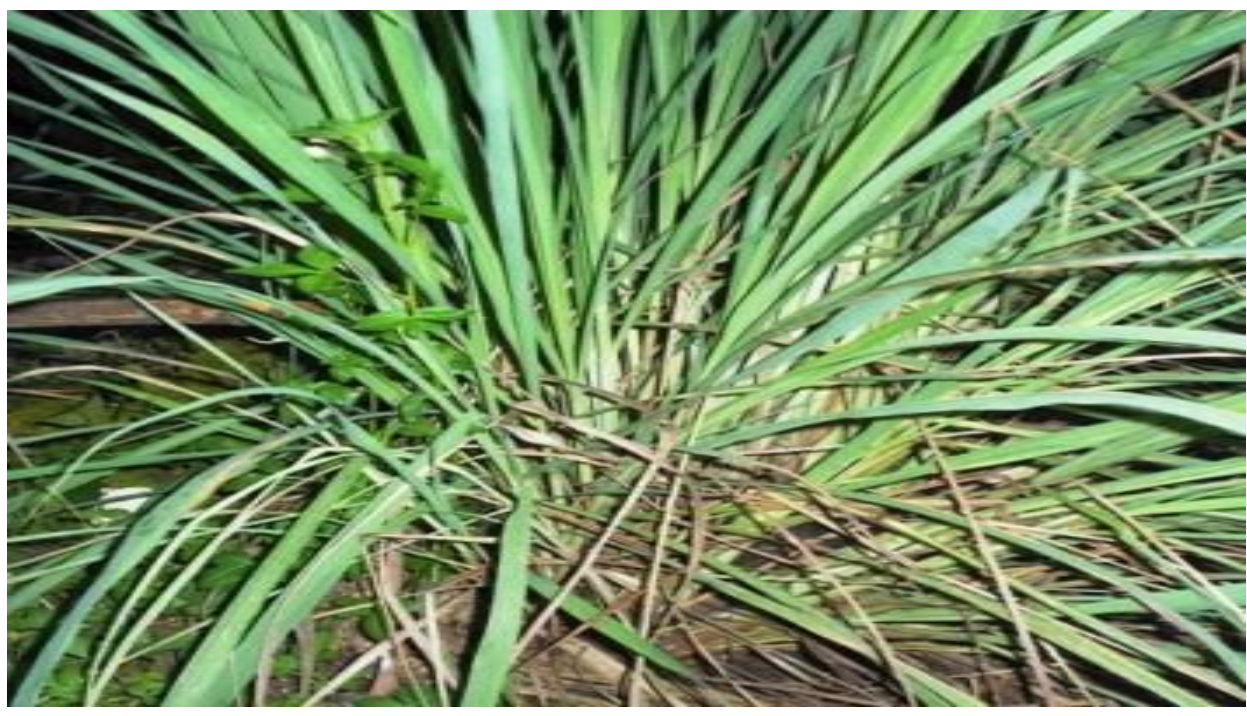

\section{Gambar 3. Pembuatan ekstrak serai}

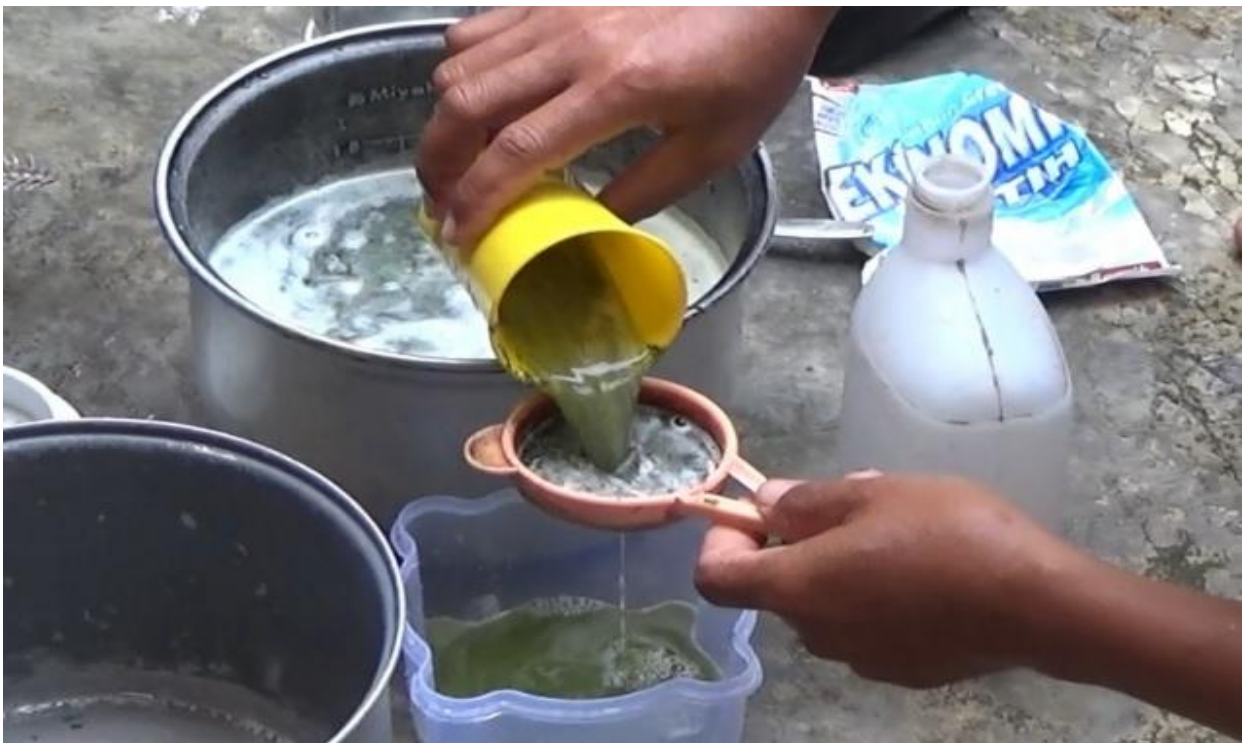


Gambar 4. Buah Sirsak yang terserang kutu kebul

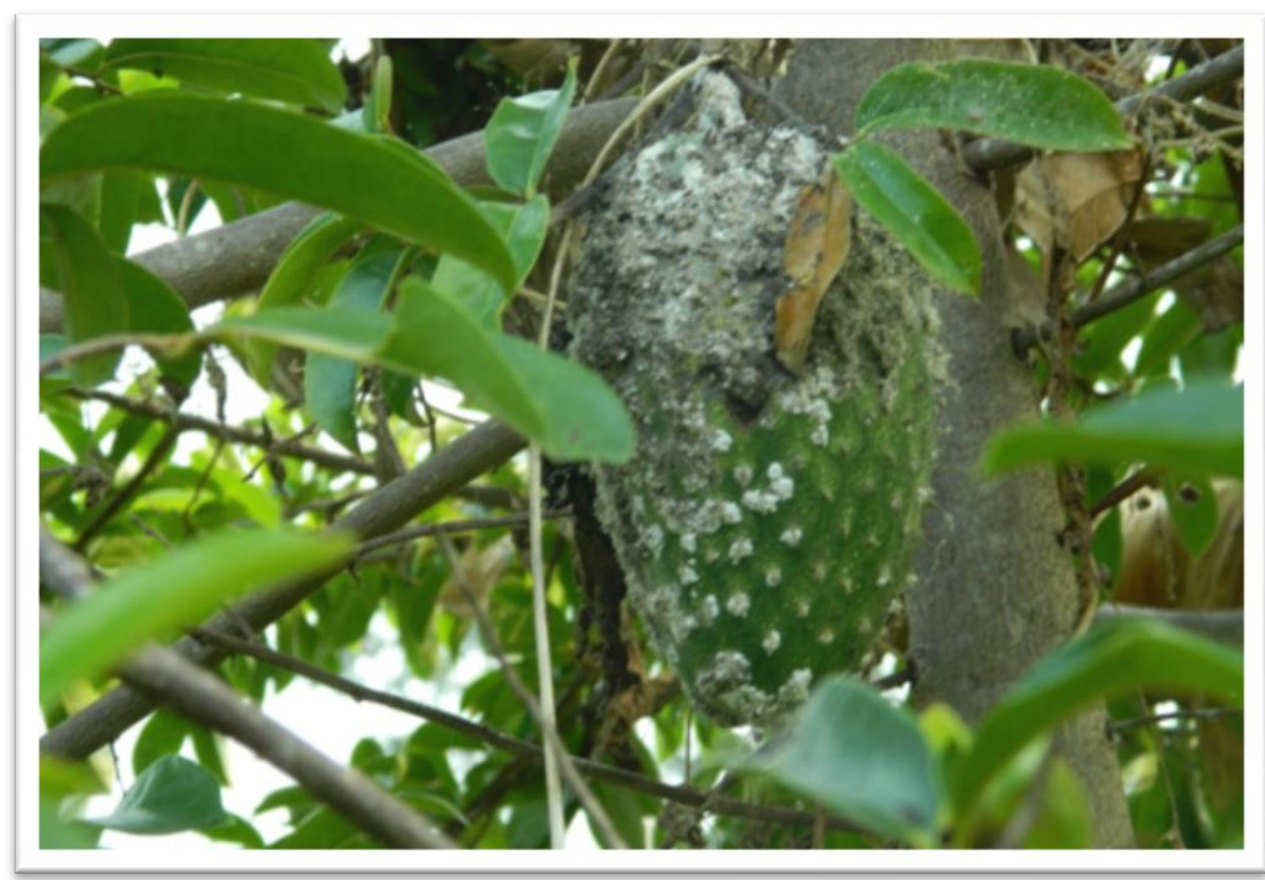

Gambar 5. Buah sirsak yang sudah melalui proses penyemprotan

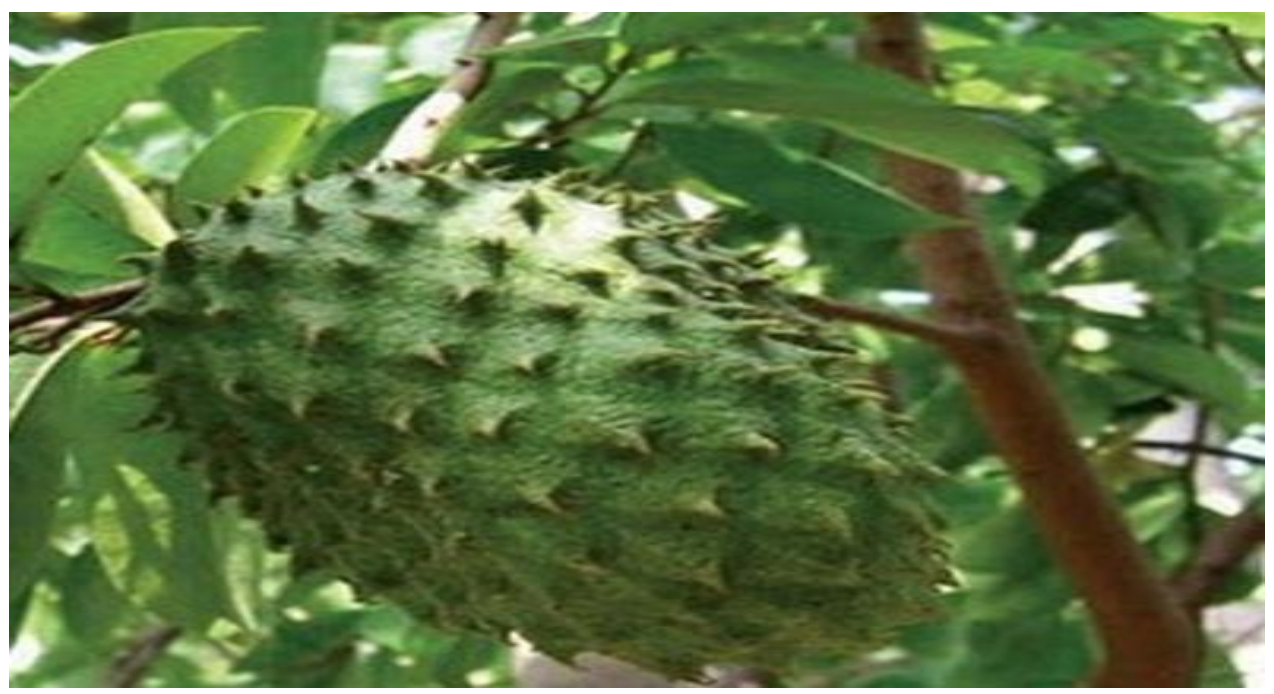

